\title{
The endangered thick-shelled river mussel (Unio crassus): a new host species for the European bitterling (Rhodeus amarus)
}

\author{
Krzysztof Tatoj ${ }^{1}$ • Adam M. Ćmiel ${ }^{1} \cdot$ Dorota Kwaśna $^{1}$ • \\ Anna M. Lipińska ${ }^{1} \cdot$ Katarzyna Zając $^{1}$ - Tadeusz Zając ${ }^{1}$
}

Received: 17 May 2016/Revised: 28 December 2016/Accepted: 13 January 2017/

Published online: 23 January 2017

(C) The Author(s) 2017. This article is published with open access at Springerlink.com

\begin{abstract}
Large freshwater mussels (Unionoida) are declining throughout the world. The European bitterling Rhodeus amarus (Bloch, 1782) female spawns its eggs inside the unionids' shells, where fertilisation and further embryonic development take place; thus its reproduction depends fully on the presence of large freshwater mussels. Unio crassus, previously regarded as one of the most numerous unionids in Europe, is now listed in the IUCN Red Data List as being globally endangered. Despite its previous prevalence, it was never reported as a host for the bitterling. A large population of $U$. crassus was studied in small river at the Świętokrzyskie Mts (Poland), where also electrofishing was conducted. In each bitterling territory located on the study plots, we found individuals of $U$. crassus, with the bitterling eggs or larvae developing on mussel's gills. That proves that this species can be also used by the bitterling for reproduction. We suggest that this relationship has not been reported to date due to the mussels' rarity and ongoing decline. However, it is also possible that the endangered mussel is a novel host for the bitterling, which is expanding its range throughout Europe.
\end{abstract}

Keywords Spawning $\cdot$ Species interaction $\cdot$ Parasitism $\cdot$ Specialisation

\section{Introduction}

The European bitterling Rhodeus amarus (Bloch, 1782) is a small cyprinid fish with a unique life cycle, characterised by an obligatory relationship with freshwater mussels. The bitterling female spawns its eggs between the gills of unionid mussels, where fertilisation

Communicated by Angus Jackson.

This article belongs to the Topical Collection: Invasive species.

Adam M. Ćmiel

cmiel@iop.krakow.pl

1 Institute of Nature Conservation, Polish Academy of Sciences, Mickiewicza 33, 31-120 Kraków, Poland 
and further embryonic development takes place (Aldridge 1999). Due to its unique mode of reproduction, the occurrence of the European bitterling is limited and depends on the presence of unionids (Przybylski and Zięba 2000). In Europe, the bitterling is mostly regarded as rare and endangered (Lelek 1987; Przybylski 2002).

The strong dependence of the bitterling on freshwater mussels has an important consequence: conservation status of the bitterling depends largely on the situation of their mussel hosts. The species of unionid mussels that commonly co-occur with the bitterling in Europe are large species of freshwater mussels, Anodonta anatina, Anodonta cygnea, Unio pictorum, and Unio tumidus (Reichard et al. 2006), which are also widespread in European inland water bodies and can fulfil key ecological functions (Gutierrez et al. 2003; Aldridge et al. 2007). However, the conservation status of these mussel species in Europe has not been studied sufficiently (Lopes-Lima et al. 2016).

The bitterling prefers to use mussels of the family Unionidae (Reynolds et al. 1997; Smith et al. 2000a, b) for reproduction, but also has been found to use those of the family Margaritiferidae (Zhul'kov AI and Nikiforov 1988; Smith and Hartel 1999). Early studies of this phenomenon reported that bitterlings were capable of using any available species of freshwater mussel for spawning (Breder 1933). However, later studies found different patterns: highly significant preferences for spawning in A. anatina, as well as in $U$. pictorum and U. tumidus, whereas A. cygnea seemed to be much less preferred (Balon 1962; Reynolds et al. 1997; Smith et al. 2000a; Mills and Reynolds 2002). Reichard et al. (2010) have confirmed that bitterlings avoid A. cygnea; however, preferences among other abovementioned mussel species tend to be related to their local abundance.

Bitterlings use almost all of the large freshwater mussels of Europe for reproduction, nevertheless, to date Unio crassus has never been demonstrated as being its host. In their review of the reproductive ecology of the bitterling, Smith et al. (2004) do not even mention $U$. crassus. It is, however, interesting that Reichard et al. $(2010,2011)$ found that in Asia Minor (Turkey) Unio crassus replaces U. tumidus as a host; thus this species can also be considered as a potential host for the European bitterling.

Unio crassus was considered the most abundant unionid species in Central and Northern Europe in the twentieth century (Israel 1913; Zwanziger 1920; Jäckel 1962; Wolff 1968; Bednarczuk 1986; Hochwald and Bauer 1990); however, this abundance is now seemingly a thing of the past. Moreover, most European unionids are lowland species, whereas $U$. crassus can inhabit the higher altitudes than other unionids (Lopes-Lima et al. 2016). In some mountainous rivers they may reach a very high density (Zajac 2004), providing the bitterling with a very large number of potential oviposition sites. Moreover, such extensive breeding possibilities, taking into consideration the range, altitude range, host population density, and ubiquity of $U$. crassus, should be valuable for a species sensitive to crowding effects (Smith et al. 2000a, b).

On the other hand, the thick-shelled river mussel $U$. crassus is assessed as endangered in Europe (Lopes-Lima et al. 2014). It is also protected in several European countries and is bred in an increasing number of active conservation projects (Lopes-Lima et al. 2016). The breeding behaviour of the bitterling in mussels is not neutral for the host. Reichard et al. (2006) demonstrated that $R$. amarus is a parasite of unionid mussels because it is able to avoid infestation by mussel larvae, while bitterling embryos developing on the gills of mussels significantly reduce the mussel's growth rate. Mills et al. (2005) showed that bitterling embryos may reduce ventilation rates by obstructing water flow through the gills and by distorting the gills and the lateral cilia on their surface. It is thus possible that a high level of abundance of the fish may affect the reproductive potential of the declining populations of $U$. crassus. 
In this paper we report the occurrence of bitterlings in a pristine river (Natura 2000 site), in which $U$. crassus is the only mussel ever found. This has inspired us to verify the role of $U$. crassus as a host for the European bitterling and to estimate the scale of this behaviour within this population.

\section{Methods}

\section{Study site}

The Warkocz (Świętokrzyskie Mts., Central Poland) is a small pristine river with a uniquely diverse hydrological system, where fast-flowing sections alternate with sections of a lentic character (flow velocity from 0 to $0.22 \mathrm{~m} / \mathrm{s}$; maximum $0.8 \mathrm{~m} / \mathrm{s}$ ). The water of the Warkocz River is relatively clean: $\mathrm{pH} 7.9$; ammonium, $0.08 \mathrm{mg} / \mathrm{dm}^{3}$; orthophosphate, $0.04 \mathrm{mg} / \mathrm{dm}^{3}$; nitrite, $0.08 \mathrm{mg} / \mathrm{dm}^{3}$; nitrate, $10.33 \mathrm{mg} / \mathrm{dm}^{3}$; calcium, $7.14 \mathrm{mg} / \mathrm{dm}^{3}$; and conductivity, $339 \mu \mathrm{S}$ (mean values for 14 May 2014). It is inhabited by several rare and endangered fish species, such as the European bitterling (Rhodeus amarus), brook lamprey (Lampetra planeri), Ukrainian brook lamprey (Eudontomyzon mariae), European bullhead (Cottus gobio), and an abundant population of thick-shelled river mussels (U. crassus).

The study was conducted at three sites (Fig. 1): (A) $50^{\circ} 50^{\prime} 24.85^{\prime \prime} \mathrm{N}, 20^{\circ} 45^{\prime} 27.81^{\prime \prime} \mathrm{E}$, length: $46 \mathrm{~m}$, mean width: $7.78 \mathrm{~m}(\mathrm{SD}=0.88 \mathrm{~m}$ ), mean water depth: $10.58 \mathrm{~cm}$ (max.: $60 \mathrm{~cm}, \mathrm{SD}=12.44 \mathrm{~cm}$ ); (B) $50^{\circ} 50^{\prime} 21.94^{\prime \prime} \mathrm{N}, 20^{\circ} 45^{\prime} 27.27^{\prime \prime} \mathrm{E}$, length: $50 \mathrm{~m}$, mean width: $8.10 \mathrm{~m}(\mathrm{SD}=0.93 \mathrm{~m})$, mean water depth: $16.87 \mathrm{~cm}(\max .: 83 \mathrm{~cm}, \mathrm{SD}=19.96 \mathrm{~cm})$; and (C) $50^{\circ} 50^{\prime} 21.47^{\prime \prime} \mathrm{N}, 20^{\circ} 45^{\prime} 22.47^{\prime \prime} \mathrm{E}$, length: $70 \mathrm{~m}$, mean width: $7.84 \mathrm{~m}(\mathrm{SD}=0.98 \mathrm{~m})$, mean water depth: $33.65 \mathrm{~cm}(\max .: 150 \mathrm{~cm}, \mathrm{SD}=28.76 \mathrm{~cm})$.

\section{Mussels' sampling and electrofishing}

Bitterlings and mussels were sampled between April and July 2015 (16 April, 15 May, 5 June, 18 June, and 2 July). Electrofishing was performed using pulsed DC Radet IUP-12 electrofishing equipment. The position of each bitterling individual was marked on the map. The fish were kept in plastic containers and were released at the locations in which they were initially caught immediately after the electrofishing session had finished.

The mussels were surveyed on 15 May, during their breeding season, where they are most active and visible. They were found by searching the sediment by eye for the presence of siphons and by inspecting sediments and tree roots by hand. Areas of uniform bottom covered with sand were sampled using a netted clam rake. The position of each individual was marked on the map. The bitterling larvae were identified and counted in the field by inspecting the mussels' gills in slightly opened shells. The positions of the mussels hosting bitterling larvae were marked separately.

\section{Results}

During all sampling sessions, 27 R. amarus individuals were found (11 adult males, 3 adult females, and 13 juveniles). Nine individuals were found at site A (3 adult males, 6 juveniles; Fig. 1a), 11 at site B (6 adult males, 3 adult females, 2 juveniles; Fig. 1b); and 7 at site $\mathrm{C}$ ( 2 adult males, 5 juveniles; Fig. 1c). Two of three females at site B were found 

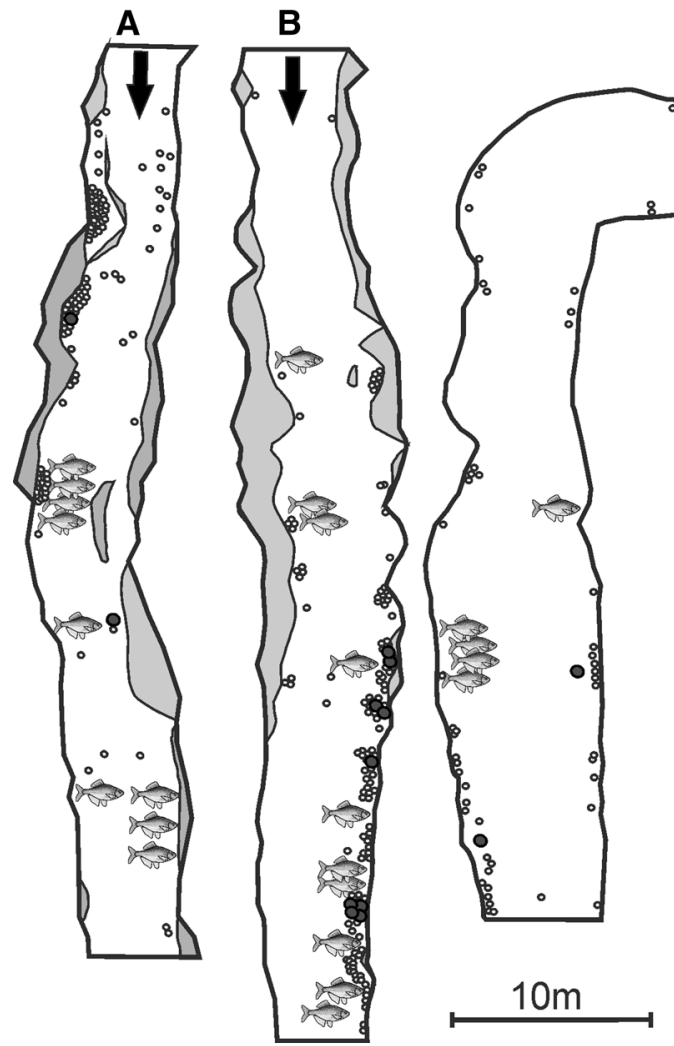

C
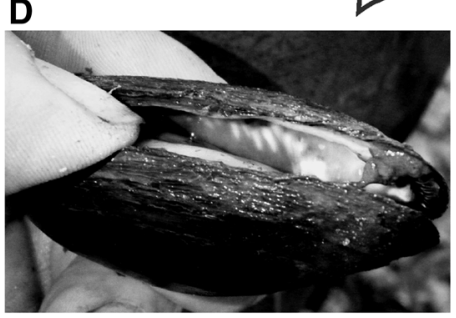

E

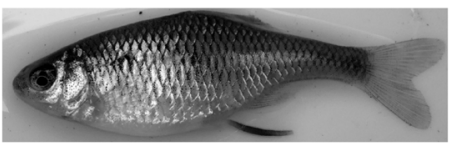

Fig. 1 Study sites $A, B$ and $C$ with marked positions of Rhodeus amarus individuals (fish icon), Unio crassus individuals (empty dots) and $U$. crassus individuals infested with bitterling larvae (dark grey dots) found on each site. Bitterling larvae were observed through the slightly opened mussel's shell $(D)$. $E$ one of the bitterling females with developed ovipositor found on the study site. Black arrows indicate the water flow

with developed ovipositors (Fig. 1e). The bitterling individuals were usually caught near the banks of the channel (mean of $1.08 \mathrm{~m}$ from the bank; $\mathrm{SD}=0.59 \mathrm{~m}$ ).

During the survey of $U$. crassus, 353 individuals were found, with a mean density equal to $0.27 \mathrm{ind} . / \mathrm{m}^{2}$ and an average of 2.12 ind. per metre of river course; 117 individuals were found at site A (mean density 0.33 ind. $/ \mathrm{m}^{2} ; 2.54$ ind. per metre of river course), 164 individuals at site B (mean density 0.40 ind. $/ \mathrm{m}^{2} ; 3.28$ ind. per metre of river course), and 72 individuals at site $\mathrm{C}$ (mean density 0.13 ind. $/ \mathrm{m}^{2} ; 1.02$ ind. per metre of river course). Their distribution within the channel on the sampling sites was non-random: $73.94 \%$ of them occurred in distinguishable clusters (shoals), each of which included from 2 to 44 individuals $($ mean $=14.5$; $\mathrm{SD}=12.35$; median $=12$ ) and which were usually located on the steep channel banks.

Inspection of the mussels' gills (Fig. 1d) revealed 15 individuals of $U$. crassus infested with $R$. amarus larvae ( $4.25 \%$ of all inspected mussels; 2 individuals at site A; 11 at site $\mathrm{B}$; 2 individuals at site $\mathrm{C}$; Fig. 1a-c). Altogether, 76 larvae were found in all the mussels (mean $=5.07 ; \mathrm{SD}=3.31$ ); $80 \%$ of the infested mussels occurred in shoals. 


\section{Discussion}

Rhodeus amarus spread throughout the freshwaters of Central Europe relatively recently. Ichthyological records show that in most European countries in which the bitterling is found today, it became widespread and common only after 1850 (Van Damme et al. 2007). Thus, the mussel species used by $R$. amarus for spawning in the western part of its geographical range appear to be hosts with a short evolutionary association with this fish species (Reichard et al. 2006). However, the question arises as why the abundant and widely distributed $U$. crassus has never been demonstrated as a bitterling host. There are three possible explanations. Firstly, although the bitterling seems to have been thoroughly studied, the pioneering British studies, conducted in a region where $U$. crassus does not occur, may have misdirected research outside Great Britain. The second explanation, which does not exclude the first, is based on the decrease in the numbers of $U$. crassus. The species seems to have been relatively abundant in the downstream parts of such lowland rivers as the Rhine, Meuse, and Schelde from about the eleventh century to the start of severe aquatic pollution in the nineteenth century (Wolff 1968). Considering that the bitterling has been spreading in Europe since the nineteenth century, the fish could not have had sufficient time and opportunities to adapt to the vanishing host species. It is also possible that the bitterling, a thermophylic species, became abundant in European lowland rivers only in the second half of the twentieth century, when $U$. crassus had already disappeared from most of those rivers, with the exception of large populations in cleaner mountainous waters (Hus et al. 2006). Thus, the third possible explanation is that when global warming started to increase sharply from ca 1980 onward, the bitterling invaded colder waters inhabited by $U$. crassus. The phenomenon may thus be a recent change.

Unio crassus has the highest altitudinal range of all European unionids (Lopes-Lima et al. 2016). U. crassus is the only mussel species harboured by the Warkocz and other mountainous rivers. Such specialisation could create a serious constraint for bitterling, restricted to lowland habitats (Thompson 1994). Thus, the new relationship between the bitterling and $U$. crassus may result from phenotypic plasticity of the parasite, enabling them to use an alternative host species in new habitat, where the preferred hosts are not available. Reichard et al. (2004a) assume that when bitterlings expand their range, their discrimination in the selection of hosts is limited, implying positive selection pressure favouring phenotypic plasticity in this species; this seems plausible here (Ghalambor et al. 2007). It is possible to imagine that mountainous rivers were inhabited by such nondiscriminative individuals of the bitterling, and this feature enabled them to colonise large, dense populations of the potential host (U. crassus), providing an opportunity for population growth and further range expansion. Additionally, in the Warkocz and other mountainous rivers, the conditions for selection pressure favouring host specialisation are completely relaxed, as there are no other species of unionids available.

In lowland rivers or floodplain lakes, ponds and postglacial lakes, such conditions are rarely met. Although new oxbows are sometimes occupied by a single species of freshwater mussels, usually unionids occur in guilds, with many species concentrated within small zones (e.g. for floodplain lakes, cf. Zając et al. 2016). This offers perfect conditions for host discrimination and the opportunity to find the most suitable individuals in terms of species and size.

The mean number of 5.07 eggs per mussel recorded in this study was far below the known maximum carrying capacity of mussels (maximum of 257 bitterling embryos per individual found in A. anatina, 147 in A. cygnea, 149 in U. pictorum, 157 in U. tumidus; 
Smith et al. 2004) and mean number of 40 embryos found in $U$. pictorum and $U$. tumidus (Reichard et al. 2004b). However, it should be remembered that these mussel species are much larger in size than $U$. crassus. The prevalence of $U$. crassus infestation $(4.25 \%)$ by bitterling embryos was also lower than in other mussel hosts for bitterling embryos (from $17 \%$ of infested Unio douglasiae individuals by Rhodeus sinensis embryos to $100 \%$ of Anodonta globosula individuals infested by Rhodeus ocellatus embryos; Reichard et al. 2007). Reichard et al. (2004a) found that the total number of bitterling eggs spawned was positively related to the number of available mussels. Thus the low mussels density recorded in the Warkocz may result in low infestation prevalence and intensity. An alternative explanation can be that $R$. amarus is still poorly adapted to the new host species. The latter hypothesis can be easily verified if the further increase in infestation prevalence and intensity will be observed for $R$. amarus along to its range spread in mountainous rivers.

Other studies indirectly confirm that $U$. crassus can be, at least locally, an important host for bitterlings. Taeubert et al. (2012) also recorded the occurrence of bitterlings in streams with large populations of $U$. crassus, although they did not report on the reproductive relationship. Doubtless, over time, the habitats now occupied (in terms of mussels) only by $U$. crassus will be invaded by the bitterling. Reichard et al. (2011) suggested that, in accordance with the evolutionary history of the parasite-host relationship, the bitterling should also infest other mussel species inhabiting Europe, if there is no counter-selection resulting from advantages of the selected species preference. These authors used this approach to explain the occurrence of bitterling larvae in $U$. crassus inhabiting Lake Sapanca in Asia Minor (Turkey). They assumed that as a result of the long history of the host-parasite relationship, Unio crassus replaces U. tumidus as a host. It could happen, however, that $U$. crassus was a common and widespread host both in Asia Minor and all across Europe; it is simply unknown, because U. crassus was not studied enough. The phenomenon we have documented indicates the possibility of ongoing evolutionary process, needing further studies on the spatial distribution of the bitterling's preferences and the resulting consequences for its population dynamics and range expansion.

Acknowledgements We thank Michał Lipiński and Wojciech Bielański for their help in the fieldwork. This study was funded by INC PAS internal grant for PhD Students No. 224/N/2015 (KT) and by the authors. The research was conducted in full compliance with the ethical codes and legislation of the Republic of Poland. KT holds a license for conducting electrofishing in accordance with Polish legal requirements.

Open Access This article is distributed under the terms of the Creative Commons Attribution 4.0 International License (http://creativecommons.org/licenses/by/4.0/), which permits unrestricted use, distribution, and reproduction in any medium, provided you give appropriate credit to the original author(s) and the source, provide a link to the Creative Commons license, and indicate if changes were made.

\section{References}

Aldridge DC (1999) Development of European bitterling in the gills of freshwater mussels. J Fish Biol 54:138-151. doi:10.1111/j.1095-8649.1999.tb00618.x

Aldridge DC, Fayle TM, Jackson N (2007) Freshwater mussel abundance predicts biodiversity in UK lowland rivers. Aquat Conserv 17:554-564. doi:10.1002/aqc.815

Balon EK (1962) Note on the number of Danubian bitterlings developmental stages in mussels. Věstn Česk Spol Zool 26:250-256

Bednarczuk J (1986) Untersuchungen zu Wirts fischspektrum und Entwicklung der Bachmuschel Unio crassus. PhD thesis, Tierärztliche Hochschule Hannover, Germany 
Breder CM (1933) Rhodeus amarus spawning in American mussels. Copeia 1933:147-148

Ghalambor CK, McKay JK, Carrol SP, Reznick DN (2007) Adaptive versus non-adaptive phenotypic plasticity and the potential for contemporary adaptation in new environments. Funct Ecol 21:394-407. doi:10.1111/j.1365-2435.2007.01283.x

Gutierrez JL, Jones CG, Strayer DL, Iribarne OO (2003) Mollusks as ecosystem engineers: the role of shell production in aquatic habitats. Oikos 101:79-90. doi:10.1034/j.1600-0706.2003.12322.x

Hochwald S, Bauer G (1990) Untersuchungen zur Populationsökologie und Fortp flanzungsbiologie der Bachmuschel Unio crassus (PHIL.) 1788. Schriftenreihe Bayerisches Landesamt für Umweltschutz Heft 97:31-49, München

Hus M, Śmiałek M, Zając K, Zając T (2006) Occurence of Unio crassus (Bivalvia, Unionidae) depending on water chemistry in the foreland of the Polish Carpathians. Pol J Environ Stud 15:169-172

Israel W (1913) Biologie der europäischen Süsswassermuscheln. K. G, Lutz

Jäckel SH (1962) Ergänzungen und Berichtigungen zum rezenten und quartären Vorkommen der mitteleuropäischen Mollusken. In: Brohmer P, Ehrmann P, Ulmer G (eds) Die Tierwelt Mitteleuropas 2. Quelle \& Meyer, Leipzig, pp 206-207

Lelek A (1987) The freshwater fishes of Europe, vol 9., Threatened fishes of EuropeAula-Verlag GmbH, Wiesbaden

Lopes-Lima M, Kebapçı U, Van Damme D (2014) Unio crassus. The IUCN Red List of Threatened Species 2014. 10.2305/IUCN.UK.2014-1.RLTS.T22736A42465628.en

Lopes-Lima M, Sousa R, Geist J, Aldridge DC, Araujo R, Bergengren J, Bespalaya Y, Bodis E, Burlakova L, Van Damme D, Douda K, Froufe E, Georgiev D, Gumpinger C, Karatayev A, Kebapc U, Killeen I, Lajtner J, Larsen BM, Lauceri R, Legakis A, Lois S, Lundberg S, Moorkens E, Motte G, Nagel KO, Ondina P, Outeiro A, Paunovic M, Prie V, von Proschwitz T, Riccardi N, Rudzıte M, Rudzıtis M, Scheder C, Seddon M, Sereflisan H, Simic V, Sokolova S, Stoeckl K, Taskinen J, Teixeira A, Thielen F, Trichkova T, Varandas S, Vicentini H, Zajac K, Zajac T, Zogaris S (2016) Conservation status of freshwater mussels in Europe: state of the art and future challenges. Biol Rev. doi:10.1111/brv.12244

Mills SC, Reynolds JD (2002) Host species preferences by bitterling, Rhodeus sericeus, spawning in freshwater mussels and consequences for offspring survival. Anim Behav 63:1029-1036. doi:10.1006/ anbe.2001.1988

Mills SC, Taylor MI, Reynolds JD (2005) Benefits and costs to mussels from ejecting bitterling embryos: a test of the evolutionary equilibrium hypothesis. Anim Behav 70:31-37. doi:10.1016/j.anbehav.2004. 09.016

Przybylski M (2002) Bitterling. In: Głowaciński Z (ed) Polish red data book of animals. Vertebrates. PWNiL, Warsaw, pp 299-301 (in Polish with English summary)

Przybylski M, Zięba G (2000) Microhabitat preferences of European bitterling, Rhodeus sericeus in the Drzewiczka River (Pilica basin). Pol Arch Hydrobiol 47:99-114

Reichard M, Smith C, Jordan WC (2004a) Genetic evidence reveals density-dependent mediated success of alternative mating behaviours in the European bitterling (Rhodeus sericeus). Mol Ecol 13:1569-1578. doi:10.1111/j.1365-294X.2004.02151.X

Reichard M, Jurajda P, Smith C (2004b) Male-male interference competition decreases spawning rate in the European bitterling (Rhodeus sericeus). Behav Ecol Sociobiol 56:34-41. doi:10.1007/s00265-0040760-2

Reichard M, Ondračková M, Przybylski M, Liu H, Smith C (2006) The costs and benefits in an unusual symbiosis: experimental evidence that bitterling fish (Rhodeus sericeus) are parasites of unionid mussels in Europe. J Evolution Biol 19:788-796. doi:10.1111/j.1420-9101.2005.01051.x

Reichard M, Liu H, Smith C (2007) The co-evolutionary relationship between bitterling fishes and freshwater mussels: insights from interspecific comparisons. Evol Ecol Res 9:1-21

Reichard M, Polačik M, Tarkan AS, Spence R, Gaygusuz O, Ercan E, Ondračková M, Smith C (2010) The bitterling-mussel coevolutionary relationship in areas of recent and ancient sympatry. Evolution 64:3047-3056. doi:10.1111/j.1558-5646.2010.01032.x

Reichard M, Bryja J, Polačik M, Smith C (2011) No evidence for host specialization or host-race formation in the European bitterling (Rhodeus amarus), a fish that parasitizes freshwater mussels. Mol Ecol 20:3631-3643. doi:10.1111/j.1365-294X.2011.05198.x

Reynolds JD, Debuse VJ, Aldridge DC (1997) Host specialization in an unusual symbiosis: European bitterlings spawning in freshwater mussels. Oikos 78:539-545. doi:10.2307/3545615

Smith DG, Hartel KE (1999) Margariferidae (Mollusca: Unionida): host for Rhodeus (Pisces: Cyprinidae). Pol Arch Hydrobiol 46:272-281

Smith C, Reynolds JD, Sutherland WJ, Jurajda P (2000a) Adaptive host choice and avoidance of superparasitism in the spawning decisions ofbitterling (Rhodeus sericeus). Behav Ecol Sociobiol 48:29-35. doi:10.1007/s002650000212 
Smith C, Reynolds JD, Sutherland WJ (2000b) Population consequences of reproductive decisions. Proc Biol Sci 7:1327-1334. doi:10.1098/rspb.2000.1146

Smith C, Reichard M, Jurajda P, Przybylski M (2004) The reproductive ecology of the European bitterling (Rhodeus sericeus). J Zool 262:107-124. doi:10.1017/S0952836903004497

Taeubert JE, Martinez AMP, Gum B, Geist J (2012) The relationship between endangered thick-shelled river mussel (Unio crassus) and its host fishes. Biol Conserv 155:94-103. doi:10.1016/j.biocon.2012. 06.005

Thompson JN (1994) The coevolutionary process. University of Chicago Press, Chicago

Van Damme D, Bogutskaya N, Hoffman RC, Smith C (2007) The introduction of the European bitterling (Rhodeus amarus) to west and central Europe. Fish Fish 8:79-106. doi:10.1111/j.1467-2679.2007. 00239.x

Wolff WJ (1968) The molluscs of the estuarine region of the rivers Rhine, Meuse and Scheldt in relation to the hydrography of the area 1 . The Unionidae. Basteria 32(1-3):13-47

Zając K (2004) Skójka gruboskorupowa Unio crassus. In: Monitoring gatunków i siedlisk przyrodniczych ze szczególnym uwzględnieniem specjalnych obszarów ochrony siedlisk Natura 2000, GIOŚ, pp 1-12 (in polish)

Zając K, Zając T, Ćmiel A (2016) Spatial distribution and abundance of Unionidae mussels in a eutrophic floodplain lake. Limnologica 58:41-48. doi:10.1016/j.limno.2016.02.002

Zhul'kov AI, Nikiforov SN (1988) Some data on the morphology and biology of the bitterling Rhodeus sericeus of the Tym' River. Sakhalin Vopr Ikhtiol 28:149-153

Zwanziger G (1920) Über die Verbreitung der Najaden im Gebiet der sächsischen Saale bei Hof. Archiv für Molluskenkunde 52:14-33 